\section{Stigma as a Challenge To Adherence To Antiretroviral Therapy Among People Living With Hiv/Aids In Nigeria - A Review}

\section{Okuku Mary Obidiya,}

Rivers State University / Rivers State University Teaching Hospital, Port Harcourt, Nigeria

\section{Dan-Jumbo Alali,}

Rivers State University Teaching Hospital, Port Harcourt, Nigeria

Submitted: 26 October 2020

Accepted: 07 December 2020

Published: 31 December 2020

Corresponding author:

Okuku Mary Obidiya

DOI: $\underline{10.19044 / \text { esj.2020.v16n36p128 }}$

(c)

Copyright 2020 Obidiya O.M,

Distributed under Creative Commons

BY-NC-ND 4.0 OPEN ACCES

\section{Cite as:}

Obidiya O.M, Alali D-J.(2020). Stigma As A

Challenge To Adherence To Antiretroviral Therapy

Among People Living With Hiv/Aids In Nigeria -

A Review. European Scientific Journal, ESJ, 16

(36), 1.

https://doi.org/10.19044/esj.2020.v16n36p128

\section{Abstract \\ Human Immunodeficiency Virus/} Acquired Immunodeficiency Syndrome (HIV/AIDS) still remains a public health challenge in Nigeria as people living with HIV/AIDS (PLWHA) do not adhere to their antiretroviral therapy (ART). Stigma is considered as a strong reason why people living with HIV/AIDS do not access HIV clinics and thus do not adhere to their treatment regimen. The objective of this study is to determine if stigmatisation affects adherence to ART. A comprehensive literature search of databases such as Medline, BioMed Central, Global Health (CABI), PUBMED, PsycINFO, Web of Science Core Collection and BMJ Best Practice was done to retrieve articles relevant for the study. Eleven (11) primary articles descriptive cross-sectional surveys (from 2008 to 2020 - adults 19 years and above) of studies conducted in Nigeria which met the inclusion criteria was selected and reviewed. The result showed that low self esteem (internalized stigma), facility based (status disclosure), community based (hostility \& restriction in family events), family based (not sharing cutleries / toilet facilities) and workplace based stigma (isolation by co-workers \& threats of employment termination) contributed to non-adherence to ART. Sex workers do not feel free accessing HIV services due to fear of possible shaming and blaming by the service providers. The introduction of HIV and AIDS AntiDiscrimination Act 2014 enhance the protection of the fundamental rights of these PLWHA. The review concludes that stigma is a key factor to non-adherence to ART in Nigeria. This study recommends 


\begin{abstract}
adoption of human rights approach, strengthening of Anti-Discrimination Laws and future research on inclusion of family members in the treatment of PLWHA in Nigeria to promote their adherence to ART.
\end{abstract}

Subject: Medicine

Keywords: HIV, AIDS, Non-Adherence, Antiretroviral Therapy, Discrimination, Stigma, Nigeria

\section{Introduction}

HIV-related stigma which is most times spiked by misinformation and myths is the negative attitude, prejudice, abuse or discrimination directed at PLWHA (Valdiserri, 2002; Rao et al., 2007). This includes being barred from accessing health care services, shunned by friends, community, family and being treated poorly in work or educational settings (Valdiserri, 2002; Dahlui, Azahar and Bulgiba, 2015). Generally in Nigeria, there are misconceptions that HIV/AIDS is a death sentence and is commonly associated with infidelity, and is perceived to be transmitted via sexual intercourse only (personal communication). The individuals mostly affected or discriminated against are MSM, sex workers and people who inject drugs, and this stigma is seen as a major reason why these persons refuse accessing care, refuse taking their ART and avoid disclosing their HIV status (Omosanya, Elegbede and Isinkaye, 2014; Dahlui, Azahar and Bulgiba, 2015; Odimegwu, Akinyemi and Alabi, 2017).

\section{HIV and AIDS Anti-Discrimination Act 2014}

The legal system in Nigeria does not favour same sex marriage and being a sex worker is a taboo in some communities in Nigeria especially the Muslim communities who practice Shari’a law (Weimann, 2010; Sulaiman, 2016). These sexual acts are seen as punishable offences and as such could highly likely deter them from accessing HIV clinics for fear of disclosing their sexual orientations and identities (Weimann, 2010; Sulaiman, 2016). There are policies and legislations put in place by the Federal Government of Nigeria to protect the rights of PLWHA so that they can have free access to HIV treatment and other services without fear of discrimination (HIV and AIDS Anti-Discrimination Act 2014; Odimegwu, Akinyemi and Alabi, 2017).

For instance, in November 2014, HIV and AIDS Anti-Discrimination Act 2014 was passed into law by the Nigerian government. This HIV/AIDS Anti-Discrimination Act 2014 was enacted to protect the dignity and 
fundamental human rights of PLWHA, through the elimination of all manner of discrimination due to their HIV status. It is also aimed at creating an environment that is supportive, both at the institutions, community and workplace. Additionally, whoever contravenes the HIV/AIDS AntiDiscrimination Act 2014 is liable to fine of $\$ 2,000,000$ (\$5565) and $\$ 500,000$ (\$1392) only for organisations and individuals respectively. Violation of this Act also attracts a 1year imprisonment or more if the offenders are unable to pay the stipulated fine (HIV/AIDS Anti-Discrimination Act 2014).

In a bid to create a global awareness on the harmful effects of stigmatization of PLWHA, every 1st of March is globally observed as Zero Discrimination Day (United Nations Programs on AIDS (UNAIDS), 2019). In a press statement on 01/03/2019 to mark the 2019 Zero Discrimination Day, the UNAIDS Executive Director Michel Sidibe, made a global appeal to all the countries to abolish discriminatory laws and treat PLWHA with respect and dignity (UNAIDS, 2019). Michel Sidibe reiterated in his press statement that there still exist some travel restrictions against PLWHA in some countries (UNAIDS, 2019). These travel ban makes it probable that there is the likelihood of PLWHA to be afraid of accessing HIV clinics or disclosing their status to avoid embarrassment by the authorities. This year on 01/03/2020, the new executive director of UNAIDS, Winnie Byanyima called for zero discrimination against women, girls and all persons vulnerable to / living with HIV/AIDS (UNAIDS, 2020). This suggests that stigmatization is still a problem and needs our collective efforts to support the PLWHA.

\section{Methods}

These databases were searched comprehensively - MEDLINE, BioMed Central, Global Health (CABI), PUBMED, PsycINFO, Web of Science Core collection and BMJ Best Practice to retrieve primary articles focusing on non-adherence to ART (from 2008 -2020 - adults 19 years and above). A high of about 9875 hits was produced for MEDLINE hence limits was applied as that is a large amount of literature to read. Studies involving children, pregnant women and those written in other languages other than English, articles on pay per view were excluded and search narrowed down to studies in Nigeria only. A detailed approach was used to search all of the other databases as well. Eleven (11) primary articles (studies carried out in Nigeria) met the objective of this study and were used for this literature review.

Inclusion criteria: Keywords used for the search include: discrimination, stigma, non-adherence, barriers, challenges, therapy, antiretroviral and Nigeria. Articles written only in English, primary research studies, articles published 2008 to 2020, full text articles and articles on adults only were selected for the study. 


\section{Results}

The eleven (11) articles chosen discussed that stigma is one of the main reasons for non-adherence to ART among PLWHA in Nigeria (see Table 1).

Table 1.The 11 primary articles that identified stigmatization as a problem to

\begin{tabular}{|c|c|c|c|}
\hline \multicolumn{3}{|c|}{ adherence to ART in Nigeria. } \\
\hline & Authors & Sample size & $\begin{array}{c}\text { Stigma \% } \\
\text { (percentage of } \\
\text { persons who linked } \\
\text { their non-adherence } \\
\text { to ART to stigma) }\end{array}$ \\
\hline 1 & Uzochukwu et al. (2009) & 174 & 22.1 \\
\hline 2 & Agu et al. (2011) & 118 & 5.6 \\
\hline 3 & Bello (2011) & 213 & 3.3 \\
\hline 4 & Okoronkwo et al. (2013) & 221 & 31.9 \\
\hline 5 & Oku et al. (2013) & 411 & 12.2 \\
\hline 6 & Chineke et al. (2015) & 400 & 12.7 \\
\hline 7 & Nduaguba et al. (2017) & 361 & 2.5 \\
\hline 8 & Odili, Obiechie and Amibor & 300 & 68 \\
\hline 9 & Afe17) & & \\
\hline 1 & Ogotunranyo and & 225 & 7.0 \\
\hline 0 & Muoghalu (2018) & & 63.6 \\
\hline 1 & Anyaike et al. (2019) & 550 & \\
\hline 1 & & 200 & \\
\hline
\end{tabular}

\section{Discussion}

Looking at Table 1, the figures suggest that fear of stigmatization affects patients and contributes to their non-adherence to ART.

Nduaguba et al. (2017), Bello (2011) and Agu et al. (2011) had the lowest levels of stigma in their studies at 2.5\%, 3.3\% and 5.6\% respectively. While Afe, Motunranyo and Ogungbade (2018) and Anyaike et al. (2019) reported the highest levels of stigma at $68 \%$ and $63.6 \%$ respectively. The reasons for the variations in the percentage of stigma in the studies could be due to their literacy levels. An uneducated individual may not understand the reasons for the need to adhere to his/her treatment regimen. The studies reported that some participants were illiterate.

In Nduaguba et al.’s (2017) study, 51.4\% of the participants had no college education, but there was peer support, home visits by nurses which may have boosted their morale and may be the reason for the low level of stigma (2.5\%) reported. Bello (2011) reported that $28.1 \%$ of the participants had only primary education while $33.8 \%$ had no formal education. Bello reported that there were uninterrupted and regular free HIV services, free ART and free drugs for patients with opportunistic infections. With the regular free 
services offered there is a possibility that a good rapport may likely have existed between patients and their caregiver through counselling which may have caused the low level of stigma (3.3\%) reported. Similarly, Agu et al. (2011) study had 5.6\% stigmatization level in the study and it was reported that there was a good interpersonal relationship between the PLWHA and their healthcare providers which may be the reason for the low level.

In contrast, Afe, Motunranyo and Ogungbade (2018) reported that $68 \%$ of the study population were illiterates and the study had the highest level of stigma recorded at $68 \%$. However, the study did not report whether the participants received peer support, family support or any form of support from their healthcare providers making it difficult to ascertain the actual cause of the high level of stigmatization reported. Anyaike et al.'s (2019) study reported that the participants who had the highest level of non-adherence to ART had no formal education (63.6\%). They also stated that the majority of the participants disclosed their HIV status to their family and were supported by their families. However, despite this family support they received, the study had high levels of stigma. The reason for this is not understood hence more research is needed to ascertain this.

These authors Kalichman et al. (2008), Nachega et al. (2012) and Wawrzyniak et al. (2013) in their survey, cross-sectional study and review respectively argued that high literacy minimises stigmatization and boosts patients' adherence to their medication regimen. Based on this, one may argue that the literacy of the participants in Anyaike et al. (2019)s study may have contributed to the high of stigma reported.

Nevertheless, a prospective study of 125 participants, conducted by Erah and Arute (2008) in Benin City, Nigeria to determine factors responsible for non-adherence to ART among PLWHA concluded that stigma and educational level were one of the major determinants of adherence levels of patients on ART. Other studies conducted outside Nigeria - South Africa, Botswana and the United States affirm that stigmatization is a factor in nonadherence to ART (Nachega, Stain and Lehman, 2004; Edward, 2006; Wolfe, Weisser and Bangsberg, 2006).

For instance, Nachega, Stain and Lehman (2004) in their one month cross-sectional study of 66 HIV positive patients to determine their ART adherence in an HIV clinic in Soweto, South Africa concluded that there was significant decline in adherence to ART which was linked to fear of stigmatization by their partners. Similarly, Edward's (2006) 2 weeks qualitative exploratory study in a hospital in Maryland, United States investigated 20 African American women who have HIV/AIDS to know their perception on the factors that hinder their ART adherence. The study concluded that perceived stigma was a major barrier to adherence to ART as many participants verbalized having relationship turbulence with their sexual 
partners and some received degrading remarks (eg. whore) from people on knowing their HIV status. Hence, this HIV-related stigma hinder them from complying to their medication regimen as they try as much as possible to avoid being seen taking their ART.

Furthermore, Wolfe, Weisser and Bangsberg (2006) in their study in 2000 in Botswana, interviewed 112 HIV patients who were on ART to find out barriers to adherence to ART and clinic attendance. The result showed that $94 \%$ and $69 \%$ of the participants kept their HIV status secret from the community and their families respectively. Other problems identified include low self esteem, fear of status disclosure in HIV clinics, fear of isolation from co-workers, fear of termination of employment due to HIV status and fear of hostility from family members. This resulted in their seeking HIV treatment late and fear of taking their ART to avoid being stigmatized. About $55 \%$ of the participants stated that stigmatization was the reason behind their nonattendance to HIV clinic. These studies demonstrate that stigmatization is a barrier to adherence to ART and should be given attention by healthcare professionals and the public so that PLWHA will feel free to take their ART and attend HIV clinics to maintain good viral load suppression.

A more recent four country study by Neuman et al. (2013) to determine factors that prevent patients from accessing HIV clinic services in Burkina Faso, Malawi, Uganda and Kenya concluded that stigmatization was also a factor which invariably could highly likely promote non-adherence to ART. Neuman et al. (2013) also maintained that with family support patients overcome the stigma. However, some analysts argued that stigmatization of PLWHA could either come from healthcare providers, family or the society at large or it could come from the patient's own perspective (Magnus et al., 2013; Stringer et al., 2016; Marshall et al., 2017). This suggests that the attitude of healthcare providers, family and society can impact positively or negatively on PLWHA and could determine their receptiveness to accessing HIV services and adhering to their medication regimen.

\section{Recommendations}

Therefore, to tackle this stigmatization which has been identified as a barrier to adherence to ART in Nigeria, there is need to promote the adoption of human rights approach and Anti-Discrimination Law should be strengthened (Odimegwu, Akinyemi and Alabi, 2017). The actual cause of the stigmatization should be investigated and tackled and HIV clinics should run inclusive services (Haghdoost and Karamouzian, 2012). The national strategies should include health service designs targeted at stigma and discrimination reduction through education and empowerment of PLWHA to understand the need to change their attitudes and address their fears (Nyblade et al., 2009). Families and communities should be educated on HIV/AIDS and 
should be involved in the care and treatment of PLWHA as this will help reduce stigma and discrimination.

Furthermore, there is a need for PLWHA to understand their human rights and act when their rights are violated (Odimegwu, Akinyemi and Alabi, 2017). In other words, if all these recommendations are enhanced and strengthened, PLWHA will be free to access HIV clinics without fear and will highly likely maintain a good adherence to their ART.

The reason why some studies reported low levels of stigma and others much higher levels is not clear and was not specified in most of the studies. Hence, there is need for more research to ascertain these variations.

\section{Conclusion}

This review conclude that family support, peer support, regular home visits by healthcare professionals, regular free HIV services, free ART, free drugs for those with opportunistic infections and above all a good interpersonal relationship between PLWHA and their healthcare providers will promote adherence to ART and reduce stigmatisation which has been identified a barrier to non-adherence to ART among PLWHA in Nigeria.

\section{References:}

1. Afe, A.J., Motunrayo, O. and Ogungbade, G.O. (2018) Factors Influencing Adherence to HAART among Patients Living with HIV Infection in Southwest Nigeria: A Cross-Sectional Analysis. Journal of HIV \& Retro Virus. 4 (1), pp.1-9.

2. Agu, K.A., Okojie, O., Oqua, D., King, R.C., Omonaiye, O., Onuoha, C., Isah, M.A. and Iyaji, P.G. (2011) Medication Adherence and Risk Factors for Non-adherence Among Patients Taking Highly active Antiretroviral Therapy. West African Journal of Pharmacy. 22 (1), pp.19-26.

3. Anyaike, C., Atoyebi, O.A., Musa, O.I., Bolarinwa, O.A., Durowade, K.A., Ogundiran, A. and Babatunde, O.A. (2019) Adherence to combined Antiretroviral therapy (cART) among people living with HIV/AIDS in a Tertiary Hospital in IIorin, Nigeria. Pan African Medical Journal. 32 (10), pp.1-12.

4. Bello, S.I. (2011) HIV/AIDS Patients' Adherence to Antiretroviral Therapy In Sobi Specialist Hospital, IIorin Nigeria. Global Journal of Medical Research. 11 (2), pp.17-26.

5. Chineke, H.N., Adogu, P.O.U., Uwakwe, K.A. and Ewuzie, M.U. (2015) Assessment of level of Adherence to Antiretroviral Therapy among Human Immune Deficiency Virus/acquired Immune Deficiency Syndrome Patients at Imo State University Teaching 
Hospital, Orlu, Nigeria. Nigerian Journal of General Practice. 13 (1), pp.21-25.

6. Dahlui, M., Azahar, N. and Bulgiba, A. (2015) HIV/AIDS related stigma and discrimination against PLWHA in Nigerian population. PLoS One. 10 (12), pp.n.k.

7. HIV and AIDS Anti-Discrimination Act 2014 (c.125) Lagos: The Federal Government Printer.

8. Edward, L. (2006) Perceived social support and HIV/AIDS medication adherence among African American women. Qualitative Health Research. 16 (5), pp.679-691.

9. Erah, P.O. and Arute, J.E. (2008) Adherence of HIV/AIDS patients to antiretroviral in a tertiary health facility in Benin City. African Journal of Pharmacy and Pharmcology. 2 (7), pp.142-152.

10. Haghdoost, A. and Karamouzian, M. (2012) Zero New HIV Infections, Zero Discrimination, and Zero AIDS-Related Deaths: Feasible Goals or Ambitious Visions on the occasion of the World AIDS Day? International Journal of Preventive Medicine. 3 (12), pp.819-823.

11. Kalichman, S.C., Pope, H., White, D., Cherry, C., Amaral, C.M., Swetzes, C., Flanagan, J. and Kalichman, M.O. (2008) The Association between Health Literacy and HIV Treatment Adherence: Further Evidence from Objectively Measured Medication Adherence. Journal of the International Association of Physicians in AIDS Care. 7 (6), pp.317-323.

12. Magnus, M., Herwehe, J., Murtaza-Rossini, M., Reine, P., Cuffie, D., Gruber, D. and Kaisser, M. (2013) Linking and retaining HIV Patients in Care: The importance of Provider Attitudes and Behaviours. AIDS Patient Care and STD. 27 (5), pp.297-303.

13. Marshall, S.A., Brewington, K.M., Allison, M.K. and Zaller, N.D. (2017) AIDS Care. 29 (11), pp.1337-1345.

14. Muoghalu, C.O. (2018) Factors influencing adherence to antiretroviral therapy among people living with HIV/AIDS attending the State Hospital, Osogbo, Nigeria. HIV \& AIDS Review. 17 (4), pp.288-298.

15. Nachega, J.B., Stain, D.M., Lehman, D.A., Hlatshwayo, D., Mothoping, R., Chaisson, R.E. and Karstaedt, A.S. (2004) Adherence to Antiretroviral Therapy in HIV-Infected Adults in Soweto, South Africa. AIDS Research and Human Retroviruses. 20 (10), pp.1053-1056.

16. Nachega, J.B., Morroni, C., Zuniga, J.M., Schechter, M., Rockstroh, J., Solomon, S. and Sherer, R. (2012) HIV treatment adherence, patient health literacy, and Healthcare provider-patient 
communication: results from 2010 AIDS Treatment for Life International Survey. Journal of the International Association of Physicians in AIDS Care. 11 (2), pp.128-133.

17. Neuman, M., Obermeyer, C., Cherutich, P., Desclaux, A., Hardon, A., Ky-zerbo, O., Namakhoma, I. and Wanyenze, R. (2013) Experiences of Stigma, Discrimination, Care and Support Among People Living with HIV: A Four Country Study. AIDS and Behavior. 17 (5), pp.1796-1808.

18. Nduaguba, S.O., Soremekun, R.O., Olugbake, O.A. and Barner, J.C. (2017) The relationship between patient-related factors and medication adherence among Nigerian patients taking highly active anti-retroviral therapy. African Health Sciences. 17 (3), pp.738-745.

19. Nyblade, L., Stangl, A., Weiss, E. and Ashburn, K. (2009) Combating HIV Stigma in health care settings: what works?. Journal of International AIDS Society. 12 (15), pp.1758-2652.

20. Odili, V.U., Obieche, A.O. and Amibor, K.C. (2017) Adherence to Antiretroviral Therapy and Its Determinants Among HIV-Infected Patients in Nigeria. Journal of Pharmacy Practice. 30 (3), pp.291295.

21. Odimegwu, C.O., Akinyemi, J.O. and Alabi, O.O. (2017) HIVStigma in Nigeria: Review of Research Studies, Policies, and Programmes. AIDS Research and Treatment. 2017 (10), pp.1-13.

22. Okoronkwo, I., Okeke, U., Chinweuba, A. and Iheanacho, P. (2013) Nonadherence Factors and Sociodemographic Characteristics of HIV-Infected Adults Receiving Antiretroviral Therapy in Nnamdi Azikiwe University Teaching Hospital, Nnewi, Nigeria. ISRN AIDS. 2013 (2013), pp.1-8.

23. Oku, A.O., Owoaje, E.T., Ige, O.K. and Oyo-ita, A. (2013) Prevalence and determinants of adherence to HAART amongst PLHIV in a tertiary health facility in south-south Nigeria. BMC Infectious Diseases. 13 (401), pp.1471-2334.

24. Omosanya, O.E., Elegbede, O.T. and Isinkaye, A.O. (2014) Effects of Stigmatization/Discrimination on Antiretroviral Therapy Adherence among HIV-infected Patients in a Rural Tertiary Medical Center in Nigeria. Journal of the International Association of Providers of AIDS Care. 13 (3), pp.260-263.

25. Rao, D., Kekwaletswe, T.C., Hosek, S., Martinez, J. and Rodriguez, F. (2007) Stigma and social barriers to medication adherence with urban youth living with HIV. AIDS Care Journal. 19 (1), pp.28-33. 
26. Stringer, K.L., Turan, B., McCormick, L., Durojaiye, M., Nyblade, L., Kempf, M., Lichtenstein, B. and Turan, J.M. (2016) HIVRelated Stigma among Healthcare Providers in the Deep South. AIDS and Behavior. 20 (1), pp.115-125.

27. Sulaiman, O.R. (2016) Shari'ah Hudud and Northern Penal Code. International Journal of Law. 2 (1), pp.8-12.

28. United Nations Programs on AIDS (2019) Message from the UNAIDS Executive Director on Zero Discrimination Day [online]. UNAIDS. Available from: http://www.unaids.org/en/resources/presscentre/pressreleaseandst atementarchive/2019/march/20190301_zdd_messsage_exd [Accessed 10/20/2020].

29. United Nations Programs on AIDS (2020) UNAIDS CALLS FOR ZERO DISCRIMINATION AGAINST WOMEN AND GIRLS [online]. UNAIDS. Available from: https://www.unaids.org/en/resources/presscentre/pressreleaseands tatementarchive/2020/march/2020-zdd-exd-message [Accessed 06/12/2020].

30. Uzochukwu, B.S.C., Onwujekwe, O.E., Onoka, A.C., Okoli, C., Ugwu, N.P. and Chukwuogo, O.I. (2009) Determinants of nonadherence to subsidized anti-retroviral treatment in Southeast Nigeria. Health Policy and Planning. 24 (3), pp.189-196.

31. Valdiserri, R.O. (2002) HIV/AIDS Stigma: An Impediment to Public Health. American Journal of Public Health. 92 (3), pp.341342.

32. Wawrzyniak, A.J., Ownby, R.L., McCoy, K. and WaldropValverde, D. (2013) Health Literacy: Impact on the Health of HIVInfected Individuals. Current HIV/AIDS Reports. 10 (4), pp.295304.

33. Weimann, G.J. (2010) Islamic Law and Muslim Governance In Northern Nigeria: Crimes against Life, Limb and Property in Shari’a Judicial Practice. Islamic Law and Society. 17 (3-4), pp.375-419.

34. Wolfe, W.R., Weisser, S.D. and Bangsberg, D.R. (2006) Effects of HIV related stigma among an early sample of patients receiving antiretroviral therapy in Botswana. AIDS Care. 18 (8), pp.931-933. 